\title{
Endophytes: Exploitation as a Tool in Plant Protection
}

\author{
Devanushi Dutta ${ }^{*}$, Keshab Chandra Puzari ${ }^{2}$, Robin Gogoi ${ }^{3}$ and Pranab Dutta ${ }^{2}$ \\ ${ }^{1}$ Specialist, Plant Protection; Krishi Vigyan Kendra; Nagaon, Assam-India. ${ }^{2}$ Department of Plant Pathology; Assam \\ Agricultural University; Jorhat, Assam-India. ${ }^{3}$ Division of Plant Pathology; Indian Agricultural Research Institute; \\ New Delhi - India.
}

\begin{abstract}
Endophytes are symptomless fungal or bacterial microorganisms found in almost all living plant species reported so far. They are the plant-associated microbes that form symbiotic association with their host plants by colonizing the internal tissues, which has made them valuable for agriculture as a tool in improving crop performance. Many fungal endophytes produce secondary metabolites such as auxin, gibberellin etc that helps in growth and development of the host plant. Some of these compounds are antibiotics having antifungal, antibacterial and insecticidal properties, which strongly inhibit the growth of other microorganisms, including plant pathogens. This article reviews the endophyte isolated from different plants, mode of endophytic infection and benefits derived by the host plant as a result of endophytism.
\end{abstract}

Key words: Antibiotics, Auxin, Endophytism, Insecticidal, Symbiotic

\section{INTRODUCTION}

Endophytes are the microorganisms, which colonize symptomless the living plant tissue without causing any immediate, overt, negative effect on the plant (Hirch and Broun 1992). Anton de Bary first introduced the term "epiphytes" for fungi that live on the surface of their host and "endophytes" for those living inside the plant tissue (De Bary 1866). Later, this term was expanded as fungi and bacteria, including actinomycetes, which spend the whole or part of their life cycle colonizing inter- or intra- cellularly, inside the healthy living tissues of the host, typically causing no apparent symptom of disease. The word endophyte came from two Greek words, "endon" means within and "phyton" means plant. Endophytes were mentioned for first time by Bary in 19th century (Azevedo 1998) and have been defined in many ways. Wilson (1995) defined endophytes as the fungi that live internally and remain asymptomatic for at least part of their lifecycle. He also described the symptomless nature of endophyte occupation in plant tissue, symbiotic and mutualistic relationship between the endophytes and their host. But they can also be aggressive saprophytes or opportunistic pathogens. Endophytes are plant-associated prokaryotes that form association with their host plants by colonizing the internal tissues, which has made them valuable for agriculture as a tool in improving crop performance (Azevedo et al. 2000). There have been several studies on the plant endophyte relationship, especially for grasses such as tall fescue, where it has been shown that endophytes produce toxins that discourage insects and other grazing animals (Bultman and Murphy 2000). Persian darnel, an annual grass, considered as a troublesome weed by wheat farmers, is probably the plant that has been studied most extensively as far as endophytes are concerned. It has been discovered that grasses with high

*Author for correspondence: devanushid@yahoo.com 
endophyte content are often resistant to attack by certain insects (Clay 1998; Bills 1996).

There has been considerable interest in screening the endophyte for bioactive compound (Kumar and Hyde 2004). A large number of compounds (secondary metabolites) have been extracted, isolated and characterized from endophytic microbes (Tan and Zou 2001; Strobel et al. 2004). This article reviews the different endophytes associated with the crop plants, their mode of infection in the plants and how plants can be benefited with endophytisms.

\section{Diversity of endophytic mycoflora in crop plants}

The first report related to the isolation of endophytic fungi from tropical host plants belonging to the families Araceae, Bromaliaceae and Orchidiceae was made by Petrini and Dreyfuss (1981). Subsequently in 1984, they also isolated few endophytic fungi from the same families in France, Brazil and Colombia. Many species of fungi colonize on living bark or twigs and small branches of conifers and broad leaved trees. Conifers such as Dogless Fir as well as deciduous tree such as Alnus is frequently colonize by Arthopyrenia plumbaria and other members of Arthopyreniaceae, including Mycoglania spp. Pirozynski and Shoemaker (1972) isolated Vestiigum felicis, an unsual Coelomycetes with cat's paw-shaped conidia from young living twigs of Thuja plicata in the Pacific Northwest of North America. Harley and Smith (1983) found that many orchids contain endophytic fungi of genus Rhizoctonia. Orchid seeds are small and lack sufficient nutrient for embryo development. The endophytic fungi grow out of the seeds after dispersal and enzymetically degrade the bark or other substrate to supply nutrient for developing orchid embryo. In an extensive survey of fungal endophytes in four cultivars on winter wheat, Sieber et al. (1988) reported Fusarium culmorum and $F$. graminearum as endophyte in all the parts of plant, except leaf and glumes. Cappellano et al. (1987) isolated Penicilliunm, an endophyte of Alnus glutinosa and A. incana, which formed specialized myconodules in association of roots, which resembled Actinorrhizae. These myconodules were confined to outer cortical layer. Cortical cells invaded by the fungus were eventually killed as the hyphae occupied the entire cell with a highly branched and convoluted hyphal mass. Penicillium and Aspergillus spp. have been recovered as endophytes in Germany. Sunmerbell (1989) reported 20 species of Penicillium from the roots of Picea mariana. He found that endophytic Penicillia and Aspergillia were widespread and heterogeneous. Leuchtman and Clay (1988) reported endosymbiotic fungal species, viz. Balansia, Epichloe and Neotyphodium in desert plant, which were protected from the effect of the desiccating environment since they were contained within the moist internal tissue of the host. Neotyphodium maintain growth within the basal meristem tissues of the grass plant.

In perennial plants, hyphae grow in the intercellular spaces of the leaf sheath and blade, typically unbranched and parallel to the leaf axis. ELISA measurements showed that the concentration of mycelium was usually highest in the base, declining upward in the sheath and above the legular zone in the leaf blade (Musgrane 1984). In the reproductive tiller, the tissue above the top node is heavily infected with endophyte, which eventually colonizes the seed embryo (Philipson and Christry 1986). Silti (2008) isolated 16 endophytic actinomycetes from the roots, stems and leaves of healthy tobacco plants. Identification based on colony and microscopy observation revealed that the majority of the isolates were Sterptomycete-like strain, with abundant mycelia and powdery spores. Katan (1971) reported $F$. oxysporum f.sp. lycopersici, the tomato wilt pathogen as root endophyte of symptomless weed species, namely Amaranthus graecizans, Digiteria sanguinalis, and Malvus silvestris, collected from the fallow tomato field in Germany. Bacon and Hinton (1996) described the distribution pattern of vegetative hyphe of $F$. moniliforme on maize. They found that hyphae were intercellular only and were present in the roots, stem internodes and leaf sheath. However, plant with disease symptom had the fungal mycelium, both intercellularly and intracellularly, but it was restricted to the cortical tissue and was not present in vascular bundle. Verma et al. (2007) isolated 233 isolates of endophytic fungi from Azadiracta indica growing in several natural habitats of India. Of which Hyphomycetes (62.2\%) were the most prevalent, followed by the Coelomycetes $(27.4 \%)$ and Mycelia sterilia (7.7\%). The dominant endophytic fungi isolated were Aspergillus spp, Phomopsis oblonga, Cladosporium cladosporioides, Drechslera, etc. Genera such as Periconia, Stenella and Drechslera were reported for the first time as endophyte from this host plant. Gond et al. 
(2007) isolated endophytic fungi from the healthy, living and symptomless tissues of inner bark, leaves and root of Aegle marmelos, a well-known medicinal plant, growing in different parts of India, including Varanasi. A total of 79 isolates of endophytes were isolated, representing 21 genera. Members of the Deuteromycotina were more prevalent than Ascomycotina and others. Maximum isolates were recovered belonging to Hyphomycetes (78.5\%), followed by Ascomycetes (8.9\%) and Coelomycetes (7.6). The dominant endophytic genera were Aspergillus spp., Curvularia spp., Nigrospora spp. and Stenella spp. Polentilla fulgens, an ethno-medicinal plant of the ethnic tribes of Meghalaya in the Eastern Himalayan range of India was screened for root fungal endophytes. Bhagaboty et al. (2010) isolated endophytes in water agar plate, which yielded a unique fungus that had similar morphological characters with the members of the genus Talaromyces. Molecular characterization using fungal specific 18s RNA primers showed that Talaromyces shared $98 \%$ homology with Penicillum verruculosum. Fungal extracts from $F$. tricinctum, Gibberella avenacea and Alternaria sp., isolated from Artemisia апnиа showed antifungal activities against Candida albicans by producing different bioactive compounds such as enniatins, moniliformin. The extract also displayed significant immune suppression in the in vitro lymphocyte proliferation (Quadri et al. 2013). Suciatmih and Rashmansyah (2013) isolated 22 endophytic fungal isolates associated with mangrove plant from Bunaken Island, Indonesia that were antagonist to Fusarium oxysporum - the wilt causing pathogen. Three of them produced volatile antifungal agent. endophyte Colletotrichum had highest antifungal behavior, followed by Aspergillus fumigatus by producing cyclohexanone, 3-octanone and phenyl alcohol.

\section{Mode of endophytic infection}

Foley (1962) described the path of infection of endophytic $F$. moniliforme on maize. This fungus was present in the nodes earlier than in internodes and confined to the basal part of the stalk until the time of flowering. During flowering, a rapid spread of mycelium was observed throughout the plant. Maize plant may become infected by endophytic $F$. moniliforme through three different routes, namely air and/or rain splash, insect damage and seed transmission (Salama and Mishricky 1973). Out of these three different routes, air and/or rain splash was the most important pathway for endophytic infection (Munkvold et al. 1997). Three methods were followed to make the maize plant infected with endophytic $F$. moniliforme, viz, seed inoculation before planting, injection of the stalk, and spraying the silk with spore suspension to air and/or rain splash. Fungal recovery percentage was recorded as 7, 38, 45 and $95 \%$ of ears when inoculation was done for seed, crown, stalk and silk, respectively. Non-pathogenic endophytic strain of $F$. oxysporum was isolated by Larkin et al. (1996) from watermelon and cucumber in US as biocontrol agent to manage the diseases caused by Fusarium pathogen. With split root technique, Larkin et al. (1996) demonstrated that induced systemic resistance was one of the modes of action of endophytic $F$. oxysporum on pathogenic Fusarium. Another study made by them on the inhibition of celery yellow disease caused by $F$. oxysporum f.sp. apii indicated that parasitic competition for the infection site was the primary mechanism .

\section{Endophytic infection strategies in trees}

Fungal endophytes of trees are horizontally transmitted via seeds, and are not known to grow into the seeds and systemically infect the plant following seed germination. Endophytic fungal tissue in the seeds may produce spores that are capable of infecting a plant that grows from the seeds. This may ensure that the endophyte can disperse with its host if seeds are carried away from an inoculum source of adult plant. Following infection, endophytes may remain dormant until triggered by natural leaf senescence, abscission or damage to grow or perhaps sporulate. If the host tissue is not immediately available for infection, such as leaf on deciduous trees in winter, the endophytes must overwinter in abscised leaf. In case of leaves and stems available year round, endophytes may not have to survive outsides of its host. Abscised plant material may become lodged in the canopy or fall to the ground and rainfall. Insects or wind could disperse the spores from abscised plant material to the endophyte-free plant tissue such as newly emerging leaves and twigs (Malloch and Blackwell 1992). When lodged in the tree canopy, rain falling through the canopy can disperse the spores and carry them to the susceptible tissue. For deciduous tree, endophytes would have to overwinter in the leaves or find an alternative substrate to colonize until new leaves emerge. However, endophytes that occupy the 
stems and evergreen foliage, which are present year round do not need to overwinter till new leaves are present.

\section{Advantages of endophytism}

Endophytism offers several advantages to the host plants. They are (i) greater access to the nutrients, (ii) protection from desiccation, and (iii) protection from the surface feeding insects, parasitic fungi, etc. Episymbiotic fungi modify the host tissue in order to acquire their nutrients. Epidermal cells in close association to stromata are hypertrophied and lack the waxy cuticle that normally prevents the escape of water and nutrients from the leaf (White and Glenn 1994). Because the cuticle is absent on the leaf, the episymbiont may extract the nutrient from the leaf across the modified epidermal layer. In case of endosymbiosis, mycelium is distributed among the internal cells of the plant tissues (White and Owens 1992). The extraction of nutrients from the host may be enhanced by modifying both internal and external tissues of the host plant to enhance the flow of nutrients to the stromal mycelium (White et al. 1997). In case of desert areas, only endophytes such as asymptomatic species of Neotyphodium, Balansia, and Epichloe may be protected from the effects of a desiccating environment since they are present within the moist internal tissues of the host plants. The surface of the plant is attacked by different insects, snails, mites, etc. The air contains spores of numerous species of fungi such as Trichoderma spp that have the capacity to parasitize the mycelium of other species of fungi. Fungal spores are parasitized by some air- borne fungi. Endosymbionts may escape all these deleterious infections that might occur on the surface of the plant.

\section{Secondary metabolites synthesized by endophytes}

Many fungal endophytes produce secondary metabolites and some of these compounds are antibiotics having antifungal, antibacterial and insecticidal properties, which strongly inhibit the growth of other microorganisms, including plant pathogens (Gunatilaka 2006).

\section{Antibiotics}

Igarashi et al. (2000) isolated 398 actinomycetes strains from the leaves, stems and roots of cultivated or wild plants. About10-20\% of the nbutanol extracts of their fermentation broths showed antagonistic activity against phytopathogenic fungi and bacteria. One of the extracts from Streptomyces sp. collected from Allium fistulosum had a potential to suppress the infection of Alternaria brassicicola on Chinese cabbage seedlings. Continuing further study, Igarashi et al. (2002) found that such an effect was dependent on a novel plant protective compound, named "fistupyrone". Their results suggested that a wide range of endophytic actinomycetes have a potential to produce antimicrobial compounds, which probably contributed to be more competitive with other microbes in the host plants. Cryptosporiopsis quercina is the imperfect stage of Pezicula cinamomea, a fungus commonly associated with the hardwood species in Europe. It was isolated by Strobel et al. (1999) as an endophyte from Tripterigeum wilfordii, a medicinal plant native to Eurasia. On Petri plates, C. quercina exhibited excellent antifungal activity against $C$. albicans. A peptide antimycotic "cryptocandin" was isolated and characterized form $C$. quercina, which was the chemical compound secreted by $C$. quercina in Petri plates having antifungal activity. "Cryptocin", a unique tetramic acid, is also produced by $C$. quercina. This compound possesess potent activity against Pyricularia oryzae as well as numbers of plant pathogenic fungi. The minimum inhibitory concentration (MIC) of this compound against $P$. oryzae being $0.39 \mu \mathrm{g} / \mathrm{mL}$ was examined as a natural chemical control agent for rice blast and used as a base modal to synthesize other antifungal compounds (Li et al. 2000). Doley and Jha (2010) isolated 253 isolates belonging to 12 genera of fungal endophytes from Rauwolfia serpentine, an important medicinal plant of Assam. They found that $58 \%$ of isolated fungi were anamorphic, followed by Ascomycotina (42\%). The recovery of Ascomycotina (68\%) was more than anamorphic fungi $(32 \%)$ during summer season. During winter season, however, fungi $(55 \%)$ were more frequent than the Ascomycotina (45\%). Species of Trichoderma, Nigrospora and Curvularia were the most frequently isolated endophytes from $R$. serpentine. The crude extract of Nigrospora spp. also showed antipathogenic activity against $F$. oxysporum and Phytophthora spp. Coombs et al. (1963) isolated 38 strains of endophytic actinomycetes from surface-sterilized wheat and barley root and tested their antagonistic activity for pathogens to wheat roots such as Gaeumannomyces graminis, $R$. solani and Pythium 
spp. They demonstrated that 17 of these isolates displayed statistically significant activity in the plant against $G$. graminis and some of them were able to control the development of disease symptoms in the treated wheat plants exposed to the former two pathogens in field soil. Li et al (2011) isolated an important endophyte Talaromyces flavus from a mangrove plant Sonnertia apetala. T. flavus is responsible to produce a new nonsesquiterpene peroxides (talaperoxides AD (1-4). This chemical may be exploited in the management of certain plant diseases.

\section{Antioxidants}

Harper et al. (2003) isolated two compounds, "pestacin" and "isopestacin" from the culture broth of Pestalotiopsis microspora, an endophyte isolated from Terminalia spp. in New Guinea. Both the compounds had antimicrobial as well as antioxidant properties. Electron spin resonance spectroscopy measurement confirmed its antioxidant properties because of their structural similarities with flavonoides. Saraswati et al. (2013) reported that fermented medium of endophytic fungus Fennelia nivea NRRL 5504 showed antioxidant property against DPPH through free radical scavenging effect. Terpenes, triterpenes, phenolic compounds, tannins, flavonoids and saponins were the antioxidant compounds isolated from the fermentation of liquid potato dextrose broth, which showed $86.51 \%$ free radical. Sadrati et al. (2013) isolated 20 endophytic fungi and 23 endophytic actinomycetes from wheat (Triticum durum). All the fungal extract showed antimicrobial activity. Penicillium sp. showed highest inhibition against C. albicans. The crude extract of Penicillium and Aspergillus had antioxidation activity with an inhibition percentage of 78.96 and 73.97, respectively.

\section{Enzymes}

When endophyte colonizes on the plant surface, they produce enzymes such as $\beta-1,3$ - glucanases, chitinases and cellulases to hydrolyze the plant cell wall. In addition, these enzymes also have a function to suppress the plant pathogen activities directly and have the capability of degrading the cell wall of fungi and Oomycetes (Gao et al. 2004). Senthilmurugan et al. (2013) isolated Botrytis sp. as endophyte from the aerial roots of Ficus benghalensis in India. The culture of this fungus produced amylase and laccase enzyme. The crude fungal extract inhibited $E$. coli and Klebsiella by producing bioactive compounds such as alkaloids, flavonoids, saponins, steroids and terpenoids.

\section{Products of endophyte with insecticidal activities}

Several endophytes are known to have anti-insect properties. Webber (1981) was probably the first to report an example of plant protection given by an endophytic fungus, Phomopsis oblonga on elm tree against the beetle Physocnemum brevilinenu. It was suggested that the endophytic fungus $P$. oblonga was responsible for reducing the spread of the Dutch elm disease causingagent Ceratocystis ulmi by controlling its vector P. brevilineum. It is believed that ergot alkaloids and mycotoxin are mainly responsible for their anti-insecticide properties. Nodulisporic acids, novel indole diterpines, isolated from Bontia daphnoides that exhibited potent insecticidal properties against the larvae of bowl fly, worked by activating insect glutamate-gated chloride channel (Demain 2000). Daisy et al. (2002) isolated another endophytic fungus, Muscodor vitigenus, from liana plant (Paullina paullinioides), which yielded naphthalene as major product. It could be used as active ingredient against common mothballs. It also showed a promising preliminary result as an insect deterrent and exhibited potent insect repellent against wheat stem sawfly (Cephus cinctus).

\section{Endophytes against nematode}

Hallman and Sikora (1994) reported that $F$. oxysporum reduced the population of plant parasitic root knot nematode in tomato roots in Kenya. They suggested that culture filtrate of endophytic $F$. oxysporum were toxic to these nematode causing inactivation and death. Shahasi et al. (2006) isolated nine endophytic $F$. oxysporum and screened for the production of secondary metabolites antagonistic to Radopholus similis in the culture. Undiluted and diluted culture filtrates were tested against the motile stages and eggs of $R$. similis. All the isolates tested in vitro showed antagonistic activity, causing paralysis of $R$. similis motile stages. The percentage of paralyzed nematodes increased with increase in the length of exposure time to the culture filtrates. After $24 \mathrm{~h}$ exposure in culture filtrates, up to $100 \%$ of the treated nematodes were paralyzed compared 
to $26.5 \%$ in the control treatments. Nematode mortality rates after $24 \mathrm{~h}$ exposure in the culture filtrates ranged from 76.4 to $100 \%$. Paralysis was reversible at lower concentrations of the filtrates. Males of $R$. similis were more sensitive to the culture filtrates than the females. Culture filtrates of all the isolates exhibited inhibitory effects on hatching of $R$. similis eggs. The results confirmed the potentialilty of using endophytic $F$. oxysporum as biological control agents against $R$. similis and for toxic derivatives from their secondary metabolism to be used as potential nematicides.

\section{Plant growth promoters}

Endophyte may promote plant growth by secreting different hormonal substances. Porter et al. (1979) reported that endosymbionts produced auxin, which enhanced the vegetative growth of the endophyte infected plants. They also reported the mechanism of increased drought tolerance in the plants due to higher ability of meristem to recover after drought condition.

\section{Mechanism of endophyte mediated plant disease resistance \\ Induction of plant resistance}

Over the past two decades, many researchers have focused on plant resistance responses to pathogens and parasites of various scales. Systemic acquired resistance (SAR) and induced systemic resistance (ISR) are the two forms of induced resistances. SAR, induced by the pathogen infection, is mediated by salicylic acid and associated with the accumulation of pathogenesis-related (PR) proteins. ISR, induced by some non-pathogenic rhizobacteria, is mediated by jasmonic acid or ethylene and is not associated with the accumulation of PR proteins (Vallad and Goodman 2004; Tripathi et al. 2008). These PR proteins comprise a variety of enzymes, some of which may act directly to lyse the invading cells, including chitinases and $\beta$-1,3-glucanases (Fukuda and Shinshi 1994), reinforce cell wall boundaries to resist infections, or induce the localized cell death. Fungal endophytes induced ISR may also associate with the expression of pathogenesisrelated genes. F. solani, isolated from the root tissues of tomato elicited induced systemic resistance against the tomato foliar pathogen, Septoria lycopersici and triggered PR genes, PR5 and PR7 expression in the roots (Kavroulakis et al. 2007).

\section{Indirect effect on enhanced plant resistance}

Plants develop several mechanisms against unfavorable environment such as drought, cold, salt stress or pathogens. Morphological and biochemical changes, including cellular necrosis, hypersensitive response and phytoalexin production respond to the various stresses rapidly. During the long term evolution, two types of innate resistance, non-specific (general) resistance and specific resistance are formed to resist the pathogens infestation (Kiraly et al. 2007). Since fungal endophytes may evolve from the plant pathogenic fungi, plant defense could be triggered by fungal endophytes such as pathogens. Actually, the defense of plant associated with endophytes is increased through resistance enhancement and secondary metabolites production.

\section{Ecological effects}

The infection process mainly depends on the host pathogen interaction. Competition of ecological niche and nutrition, hyperparasites and predation are between diverse micro-organism that live in endophytic niche, especially between the endophytes and pathogens. Endophytic colonization occupy ecological niche and leave no space for the pathogens, which could be the common reason for the fungal endophytes inhibiting the pathogen infection in the plant.

\section{Occupation of ecological niche}

Fungal endophytes have the ability to colonize inter- or intra-cellularly. The colonization process involves several steps, including host recognition, spore germination, penetration of the epidermis and tissue multiplication. Once the endophytes are successfully colonized in the host tissue, the endophytic niche becomes established. In the endophytic niche, endophytes will obtain a reliable source of nutrition from the plant fragment, exudates and leachates and protect the host against other microorganisms (Gao et al. 2010). Fungal endophytes are generally thought to protect the plant by rapid colonization and thereby exhausting the limited available substrates so that none would be available for pathogens to grow (Pal and Gardener 2006). Furthermore, the plants produce lignin and other cell-wall deposits to limit the growth of endophytes and cause it to be a virulent (Harman et al. 2004). As a result, the cell wall becomes re-reinforced after endophytic colonization, thus it becomes difficult for pathogens to infest. 


\section{Hyperparasitism and predation}

Hyperparasitism is another ecological strategy that endophytes provide to protect the host plant. In hyperparasitism, the pathogen is directly attacked by a specific endophyte that kills it or its propagules. Fungal endophytes parasitize around the hyphae of pathogens by various means such as coiling, twisting, penetrating the hyphae of pathogens and secreting lyase to decompose the cell wall of pathogens. Microbial predations are the mode of action of endophyte to suppress the plant pathogens. Trichoderma produces a range of enzymes that are directly used against the cell walls of fungi to utilize the fragment of pathogens (Gao et al. 2010).

\section{CONCLUSION}

Endophytes are naturally occurring biocontrol agents with potential beneficial uses in the plant. Of the nearly 3,00,000 plant species, that exist in the earth, each individual is the host to one of more endophytes. Only a few of these plants have ever been completely studied relative to their endophytic biology. The use of endophytic microorganism for the plant disease control is relatively new and unexplored area of research. Little is known about the interaction between the endophytes, host plant and pathogen. Understanding of this interaction is essential for the development of proper biocontrol strategy. Although scientific approaches on the diversity of endophytes have just recently got momentum, information on endophytes' behavior, their mutualistic interaction with crops remain scanty and more studies are needed to explore their full potentiality in plant protection sector.

\section{REFERENCES}

Azevedo JL, Maccheroni JW, Pereira JO, Luiz de Araujo W. Endophytic microorganisms: a review on insect control and recent advances in tropical plants. Electron J Biotechn. 2000; 3(1): 40-65.

Azevedo JL. Microorganismos as endofiticos. In: Melo IS and Azavedo JL, editors. Ecologia Microbiana, Brazil: Editora Embrapa, Jaguariuna, Sao Paulo; 1998. p. 117-137.
Bacon CW, Hinton DW. Symptomless endophytic colonization of Maize by Fusarium moniliforme. Can J Botany. 1996; 74: 1195-1202.

Bhagaboty RK, Joshi K, Kumar R. Penicillum veruculosum RS7PF: A root fungal endophyte associated with an ethno medicinal plant of the indigenous tribes of Eastern India. Afr J Microbiol Res. 2010; 4(6): 766-770.

Bills GF. Isolation and analysis of endophytic fungal communities from woody plants. In: Redlin SC, Cams LM, editors. Endophytic Fungi in Grasses and Woody Plants: Systemic Ecology and Evolution. St Paul: APS Press; 1996. p. 31-65.

Bultman TL, Murphy JC. Do fungal endophytes mediate wound-induced resistance? In: Bacon $\mathrm{CW}$ and White JF, editor. New York: Marcel Dekker; 2000. p. 421-452.

Cappellano A, deQuartre B, Valla G, Moiroud A. Root nodule formation by Penicillum sp. on Alnus glutinosa and A. incana. Plant Soil. 1987; 104: 45-51.

Clay K. Fungal endophytes of grasses: a defensive mutualism between plants and fungi. Ecol. 1988; 69: $10-16$.

Coombs JT, Michelson PP, Franco CMM. Evaluation of endophytic actinomycetes as antagonists of Gaeumanno- myces graminis var. tritici in wheat. Biol Control. 1963; 29: 359-366.

Daisy BH, Strobel GA, Castilo U, Ezra D, Scars J, Weaver D, et al. Nepthalene- an insect repellent, is produced by Muscodor vitigenus, a novel endophytic fungus. Microbiology. 2002; 148: 3737-3741.

De Bary A. Morphologie and Physiologie der Pilze, Flechten and Myxomyceten, Holfmeister's Handbook of Physiological Botany. Germany : Leipzig; 1866. vol. 2.

Demain AL. Microbial natural products: a past with a future. In: Wringley, S.K., Hayes, M.A., Thomas, R., Chrystal, E.J.T., Nicholson, N. editors. Biodiversity: a new leads for pharmaceutical and agrochemical industries. Cambridge: The Royal Society of Chemistry. 2000. p. 3-16.

Doley P. Jha DK. Endophytic fungal assemblages from ethnomedicinal plant Rauwolfia serpentina (L) Benth. J Plant Pathol Microbiol. 2010; 40(1): 44-48.

Foley DC. Systemic infection of corn by Fusarium moniliforme. Phytopathology. 1962; 52: 870-872.

FukudaY, Shinshi H. Characterization of a novel cisacting element that is responsive to fungal elicitor in the promoter of a tobacco class I chitinases gene. Plant Mol Biol. 1994; 24: 485-493.

Gao FK, Dai CC, Liu XZ. Mechanism of fungal endophytes in plant protection against pathogen. Afr J Microbiol Res. 2010; 4(13): 1346-1351. 
Gond SK, Verma VC, Kumar AJ, Kumar V, Kharwar RN. Study on endophytic fungal community from different parts of Aegle marmalos Correae (Rutacaea) From Varanasi, India. World J Microb Biot. 2007; 23(10): 371-375.

Gunatilaka AAL. Natural products from plantassociated microorganisms: distribution, structural diversity, bioactivity, and implications of their occurrence. J Nat Prod. 2006; 69: 509-526.

Hallman J, Sikora RA. Influence of Fusarium oxysporum, a mutualistic fungal endophyte on Meloidogyne incognita infection of tomato. J Plant Disease Prot. 1994; 101: 475-481.

Harley JL, Smith SE. Mychorrizal Symbiosis. New York: Academic Press, 1983, p.123-127.

Harman GE, Howell CR, Viterbo A, Chet I, Lorito M. Trichoderma species-opportunistic,avirulent plant symbionts. Natural Review. 2004; 2: 43-55.

Harper JK, Ford EJ, Strobel A, Grant DM, Porco J, Toner DP, et al. Pestacin: a1,3- dihydroisobenzofuran from Pestaliopsis microspora possessing antioxidant and antimycotic activity. Tetrahedron. 2003; 59: 2471-2476.

Hirsch G, Braun U. Communities of parasitc microfungi. In: Winterhoff W, editor. Handbook of vegetation science. Kluwer Academic Publisher; 1992. p. 225-250.

Igarashi Y, Iida T, Sasaki Y, Saito N, Yoshida R, Furumai $\mathrm{T}$. Isolation of actinomycetes from live plants and evaluation of antiphytopathogenic activity of their metabolites. Actinomycetologica. 2000; 16: 9-13.

Igarashi Y, Ogawa M, Sato Y, Saito N, Yoshida R, Kunoh H, et al. Fistupyrone, a novel inhibitor of the infection of Chinese cabbage by Alternaria brassicicola, from Streptomyces sp. J Antibiot. 2002; 53: 1117-1122.

Katan J. Symptomless carriers of the tomato Fusarium wilt pathogen. Phytopathology. 1971; 61: 1213-1217.

Kavroulakis NS, Zervakis GI, Ehaliotis C, Haralampidis K, Papadopoulou KK. Role of ethylene in the protection of tomato plants against soil-borne fungal pathogens conferred by an endophytic Fusarium solani strain. J Exp Bot. 2007; 58: 38533864.

Kiraly L, Barna B, Kiraly Z. Plant resistance to pathogen infection: forms and mechanisms of innate and acquired resistance. J Phytopath. 2007; 155: 385396.

Kumar DSS, Hyde KD. Biodiversity and tissue recurrence of endophytic fungus from Tripterygium willfordii. Fungal Divers. 2004; 17: 69-90.
Larkin RP, Hopkins DL, Martin FN. Suppression of Fusarium wilt of watermelon by non pathogenic Fusarium oxysporum and other microorganism recovered from a disease suppressive soil. Phytopathology.1996; 86: 812-819.

Leuchtman A, Clay K. Atkinsonella hypoxylon and Balansia cyperi, epibiotic members of the Balansieae. Mycologia.1988; 80: 192-199.

Li JY, Strobel GA, Harper JK, Lobkovsky E, Clardy J. Cryptocin, a potent tetramic acid antimycotic from the endophytic fungus Cryptosporiopsis quercina. Org Lett. 2000; 2: 767-770.

Li H, Haang H, Saho C, Huang H, Jiang J, Zhu X, et al. Cytotoxic norsesquiterpene peroxides from endophytic fungus Talaromyces flavus isolated from mangrove plant Sonneralia apetala. J Nat Prod. 2011; 74(8): 1230-1235.

Malloch D, Blackwell M. Dispersal of fungal diasporas. In: Carroll GC, Wicklow DT, editors. The Fungal Community: Its Organization and role in the Ecosystem. New York: Marcel Dekker; 1992. p. 147-171.

Munkvold GP, Hellmich RL, Showers WB. Reduced Fusarium ear rot and symptomless infection in kernals of Maize. Phytopathology. 1997; 87: 107117.

Musgrane DR. Detection of an endophytic fungus of Lolium perenne using enzyme linked immunosorbent assey (ELISA). New Zeal J Agr Res.1984; 27: 283288.

Pal KK, Gardener BM. Biological control of plant pathogens. The plant health Instructor. 2006; DOI: 10.1094/PHI-A-2006-1117-02.

Petrini O, Dreyfuss M. Endophytische plize in epiphytischen Araceae, Bromaliaceae and Orchadiaceae, Sydowia. 1981; 34: 135-148.

Philipson MN, Christry MC. The relationship of host and endophyte during flowering, seed formation and germination of Lolium perenne. New Zeal J Bot. 1986; 24: 125-134.

Pirozynski KA, Shoemaker RA. Vestigium, a new genus of coalomycetes. Can J Botany. 1972; 50: 1103-1165.

Porter JK, Bacon CW, Robins JD. Ergosine, ergosinine and chanoclaveine I from Epichloe typhina. J Agricult Food Chem. 1979; 27: 595-598.

Qadri M, Johri S, Shah A, Khajuria A, Lattoo SK, Abdin MK. Identification and bioactive potential of endophytic fungi isolated from selected plants of the Western Himalayas. Spinger Plus. 2013; 2:8. Published online Jan 11, 2013. doi: 10.1186/21931801-2-8 Available from http://www.springerPlus. com/content/2/1/8 
Sadrati N, Duoud H, Zerroug A, Duhamna S, Bouharati S. Screening of antimicrobial and antioxidant secondary metabolites from endophytic fungi isolated from wheat (Triticum durum). J Plant Prot Res. 2013; 53(2): 128-136.

Salama AM, Mishricky AG. Seed transmission of Maize wilt fungi with special reference to Fusarium moniliforme Sheld. Phytopathology. 1973; 77: 356362.

Saraswaty V, Srikandace Y, Simbiyani NA, Jasmansyah Sutiyanto H, Udin Z. Antioxident activity and total phenolic content of endophytic fungus Fennellia nivea NRRL 5504. Pak J Biol Sci. 2013; 16(22): 1574-1578.

Senthilmurugan VG, Sekar R, Kuru S, Balamurugan S. Phytochemical screening, enzyme and antibacterial activity analysis of endophytic fungi Botrytis sp. isolated from Ficus benghalensis (L.). Int J Pharm Res Biol Sci. 2013; 2(4): 264-273.

Shahasi A, Dubois Y, Viljoen A, Nico L, Ragama P, Niere B. In vitro antagonism of endophytic Fusarium oxysporum isolates against the burrowing nematode Radopholus similis. Nematology. 2006; 8(4): 627636.

Sieber T, Riesen TK, Muller E, Fried PM. Endophytic fungi in four winter wheat cultivars (Triticum aestivum L.) differing in resistance against Stagonospora nodorum (Berk.). J Phytopath. 1988; 122: 289-306.

Silti ISM. Isoaltion and characterization of endophytic actinomycetes of Tobacco plants. J Agrisystem. 2008; 4(2): 212-228.

Strobel GA, Daisy B, Castillo U, Harper J. Natural products from endophytic microorganisms. J Nat Prod. 2004; 67: 257-268.

Strobel GA, Milln RV, Condron M, Teplow DB, Hess WM. Cryptocandin- a potent antimycotoic from endophytic fungus Cryptosporiopsis quercina. Microbiology. 1999; 145: 1919-1926.

Suciatmih, Rahmansyah M. Endophytic fungi isolated from mangrove plant and have antagonism role against Fusarium wilt. ARPN J Agril Biol Sci. 2013; 8(3): 253-257.
Sunmerbell RC. Micro fungi associated with the micorrhizal mantle and adjacent microhabitats within the rhizosphere of black spruce. Can J Botany. 1989; 67: 1085-1095.

Tan RX, Zou WX. Endophytes: a rich source of functional metabolites. Nat Prod Rep. 2001; 18: 448459.

Tripathi S, Kamal S, Sheramati I, Oelmuller R, Varma A. Mycorrhizal fungi and other root endophytes as biocontrol agents against root pathogens. Mycorrhiza. 2008; 3: 281-306.

Vallad GE, Goodman RM. Systemic acquired resistance and induced systemic resistance in conventional agriculture. Crop Sci. 2004; 44: 19201934.

Verma VC, Gond SK, Kumar A, Kharwar RN, Gary S. The endophytic mycoflora of Bark, leaf and stem Tissues of Azadiracte indica A Juss (Neem ) from Varanasi (India). Microbial Ecol. 2007; 54: 119-125.

Webber J. A natural control of Dutch elm disease. Nature. 1981; 292: 449-451.

White JF, Jr., Bacon CW, Hinton DM. Modification of host cell and tissues by the biotrophic endophyte Epichloe amarillans. Can J Botany.1997; 75: 10611069.

White JF, Jr., Glenn AE. A study on two fungal epibionts of grasses: Structural features, host relationship and classification in the genus Myriogenospora. Am J Bot. 1994; 81: 216-223.

White JF, Jr., Owens JR. Stromal development and matting system of Balansia epichloe, a leaf colonizing endophyte of warm season grasses. Appl Environ Micob. 1992; 58: 513-519.

Wilson D. Endophyte - the evolution of the term, a clarification of its use and definition. Oikos. 1995; 73: 274-276. 